\title{
Land as an Object of Land Relations: Constitutional and Legal Aspect
}

\author{
Andrii Pravdiuk ${ }^{1}$ \\ ${ }^{1}$ Vinnytsia National Agrarian University \\ 3 Sonyachna Street, Vinnytsia, 21000, Ukraine
}

DOI: $10.22178 /$ pos.71-1

LCC Subject Category: K3154-3370

Received 04.05.2021

Accepted 27.06.2021

Published online 30.06.2021

Corresponding Author:

a.pravd4449@gmail.com

(C) 2021 The Author. This article is licensed under a Creative Commons Attribution 4.0 License @ (1)

Abstract. The article examines constitutional and legal problems of the study of the object composition of land relations. Analysis of scientific views in the national legal doctrine on interpreting the meaning of the term "land" is carried out. It is concluded that the basic principles of land relations are declared in the Constitution of Ukraine, and their analysis enables us to argue that a land is a unique object of legal relations. In the Constitution of Ukraine, the term "land" is used in several meanings, namely as the object of property rights of the Ukrainian people; the object of property rights of citizens, legal entities and the state; the object of the law of the territorial community; the object of special protection by the state. Thus, land relations have a particular subject and object composition. The specific features of the land as an object of legal relations declared in the Constitution of Ukraine determine the content of land relations.

Keywords: Constitution of Ukraine; land; constitutional norms; land relations; subject of legal relations.

\section{INTRODUCTION}

The constitutional regulation of land relations, which considers the land as a particular object, needs a comprehensive study, especially at the present stage of land reform. The norms enshrined in the Constitution of Ukraine, which regulate land relations, are not displayed correctly inland, civil and economic legislation. Without observance of the relevant constitutional principles and the rule of law in land relations, it is not possible to successfully carry out land reform, introduce a land market, and effectively fight corruption in the field of land relations. Since the main elements of the constitutional right of land ownership are the subjects and a particular object of land relations, i. e. land, the study of its constitutional and legal essence is an urgent problem of the modern science of constitutional law.

Many scientists have studied land as an object of legal regulation, in particular V. I. Andreitsev, H.I. Baliuk, O.H. Bondar, O.A. Vivcharenko, A. P. Hetman, M. S. Dolynska, T. O. Kovalenko, I. O. Kovaliv, T. H. Kovalchuk, I. O. Kostiashkin, P.F.
Kulynych, V. I. Lebid, I.V. Ozymok, A. M. Miroshnychenko, V. L. Muntian, V. V. Nosik, O. M. Pashchenko, V. D. Sydor, Y. M. Shevchenko, M.V. Shulha, V. I. Fedorovich and many others. In conditions of land reform, the interest in this issue is only growing. Since the constitutional and legal regulation of land relations is fundamental, studying the land as an object of land relations in the constitutional and legal aspect is extremely important.

\section{RESULTS AND DISCUSSION}

The Constitution of Ukraine as the Basic Law plays a paramount role in the regulation of land relations. The Constitution is a legal basis for the formation, development and improvement of land legislation, and the constitutional principles are fundamental, primary for the formation and development of land law. Constitutional norms are the basis for the formation of legal institutions of land law. They outline the range of social relations that are part of the subject of legal regulation of land law, consolidate and regulate the foundations of these relations [23, p. 249]. 
The concept of "land", depending on the context, is used in many senses: (1) as a planet, (2) as a land, (3) as soil, i. e., the upper layer of the earth's surface suitable for plant life, (4) as an economical category, i.e. a common means of work and the primary means of production in agriculture, (5) as an area with land plots owned by someone, an area with a legal regime, etc. There may also be different approaches to filling the concept of "land" with specific meaning [13, p. 16].

As an object of land relations, the land is the most critical component of the natural environment, which is part of the earth's crust, which is a spatial basis of the landscape above the subsoil and is used as a means of production in agriculture and forestry to locate various objects [15, p. 161].

Legislative consolidation of land as an object of land relations requires clarification of the conceptual foundations of land law, which are presented in the legal structure of the Constitution of Ukraine.

Article 13 of the Constitution of Ukraine defines the constitutional and legal regime of land, subsoil, water resources, atmospheric air, flora and fauna, nature reserve fund and other natural resources within the territory of Ukraine, as well as natural resources of its continental shelf and exclusive (marine) economic zones, clarifies the social function of property on their use, establishes guarantees of protection by the state of all subjects of the property right and economic activity that are equal before the law.

Provisions of Article 14 of the Constitution of Ukraine specify basic land use principles, declaring that land is the central national wealth under the state's special protection. The state guarantees the right of ownership. It is an absolute right being under the special protection of the state. Land ownership is acquired and exercised by citizens, legal entities and the state exclusively by the law [6].

Considering the extreme importance of land in all spheres of life of Ukraine and its people, the Constitution separates land from another real estate. It introduces the principle of its exceptional protection by the state. This protection aims to preserve land fertility, increase its productivity, use land resources according to their natural purpose, prevent land contamination with harmful elements to human and animal health, etc. However, this does not mean the exclusion of land from the system of economic relations. It is only a question of the legislative introduction of some restrictions of freedom of its use. The Constitution guarantees the right to own land, which can exist both as a right of private property and a right to state and communal property. This right is acquired by the relevant entities exclusively by law. The same guarantees provide the constitutionally possible forms of land ownership as the owner of any other objects.

Article 14 of the Constitution of Ukraine develops introductory provisions enshrined in Article 13 of the Basic Law. It determines the structure of land legislation and establishes basic principles of regulation of land relations in current conditions and the future. It also defines the legal regime of one of the most important natural resources, i. e. land, which is recognized as the primary national wealth under the special protection of the state. These provisions create a fundamentally new constitutional basis in Ukraine for both sectoral (land and civil) legislation and economic activity [18, p. 130].

According to Sydor V. [22, p. 231], the legislator states a priority role of land, considering its functions in human life and the increase of national heritage. Thus, the land is a kind of object of the material world, but unique in its origin, which requires a special regime of protection in the process of use and reproduction by the state because it is the material and spatial basis of the state and territorial organization, its independence, sovereignty, territorial integrity and national security.

As an object of legal regulation, land has the following features: it is not a product of human labour; it has its unique properties as the most critical component of the natural environment; it is a rather complex economic object, which has a large number of different properties, and therefore falls within the scope of regulation of various branches of law. The main factors of influence derived from the features of the land, which determine the nature of land relations, include [19, p. 133]:

1) spatial limitations of land, which necessitates its delimitation;

2) presence of socio-economic forms of land tenure and land use;

3) constancy of the land location;

4) land heterogeneity, which determines the rent and price of land. 
The peculiarities of land as an object of legal regulation are explained by the diversity of functions it performs, its essential role in human life and economic activity. The scientific literature, in particular, indicates the environmental, political, economic and social functions of the land. In addition, some other functions, including aesthetic (cultural), the function of the object of waste disposal, the object of environmental emergencies, settlement, communication and others functions, are identified [12, p. 27].

From the perspective of the law theory, the main elements in all legal relations are the object, subject, content (subjective rights and responsibilities), which constitute the structure of social relations governed by law rules. In this case, the objects of legal relations are phenomena (objects) of the material and spiritual world, which are recognized as such in the manner prescribed by law and aimed at personal rights and responsibilities. In jurisprudence, the object category is not directly related to the subject, like philosophy. Still, it is understood in another, particular (legal) aspect so that the objects are considered only part of legal relations. According to Nosik V. [15, p. 182], taking into account these general theoretical approaches to the analysis of the composition of legal relations, it should be noted that implementation of the constitutional principles of land ownership will largely depend on how the current legislation of Ukraine will define the concept of land as an object in the structure of land and property relations.

It should be noted that the problem of the concept, content, classification and analysis of the object of land relations is essential because only the presence of the object of law necessitates the emergence and implementation of the legal relations. After all, it is well known that the absence of the object of law deprives any legal relationship of any sense of existence.

Land relations have a particular subject and object composition. According to Article 2 of the Land Code, land relations are public relations concerning the possession, use and disposal of land. The subjects of land relations are citizens, legal entities, local governments and public authorities. Objects of land relations are lands within the territory of Ukraine, land plots and rights to them, including land shares [4].

As social relations, they have such standard features as the order, ongoing nature, particular social roles of participants concerning the land. The features of land relations as legal relations are based on the fact that their emergence, change or termination are based on the rules governing relations concerning land and the fact that the state ensures implementation of these rules. The general content of social roles in land legal relations is manifested in the presence of the participants in these legal relations of the relevant rights and responsibilities aimed at ensuring the interests related to land use. Thus, in the most general form, land legal relations can be considered the relations that arise, change, and terminate due to the settlement of socially significant, protected interests concerning land use to meet society's basic needs. Referring to the main points that outline the range of land relations that can be subject to regulation, the fact that it is, firstly, social relations, secondly, volitional relations, and thirdly, their object is the land [19, p. 121].

There seem to be quite interesting the arguments of Sydor V. [23, p. 231], who notes that land as an object of social relations, even when human labour is applied to it and funds are invested, continues to be an object of nature. This is one of the main features of the land, which is the object of social relations and land relations. Land as a natural object is characterized by irreplaceability for humans, limited territory (size), locality by the placement and real estate. Its natural origin determines land limitations. It can neither be reduced nor increased. People are forced to use the objectively given territory that has been determined by nature. As the scientist notes, "this is especially true of its best part - the fertile layer, the size of which can be reduced due to careless land management, which often happens in real life. Localization of land plots by their placement is also determined by natural origin. Each particular land plot is located in a strictly defined geographical place and cannot be transferred by human forces to another place. It may change its owners, users, tenants, but not its place. According to the rules of land management, to determine the right of ownership or use for a particular entity to whom the land plot has been granted".

As an object of land relations, land has its specifics determined by such parameters as the geographical location of the area and a set of its natural characteristics, which determine the nature of land use; structure, qualitative composition and current condition of lands; the current size of land use by different categories of agricultural producers, etc. Thus, the established natural het- 
erogeneity of land creates a corresponding differentiation of the legal regime depending on the categories, zones, and other land features.

The land is the primary basis for the state existence, so specific features of land relations provide for the mandatory participation of the state in the process of their regulation. After all, recognition of land as a particular object of legal relations imposes on landowners and land users certain obligations in exercising their rights as participants of land relations and certain restrictions in the interests of society or particular social groups. "Establishment of appropriate restrictions on the behaviour of the subjects of land relations is performed through the state intervention in these legal relations. Disclosing an optimal degree of state (public) influence on the behaviour of subjects of land relations to harmonize the interests of individuals, social groups, society is a central problem of administrative and legal regulation of land relations, which is solved by the state through a system of measures aimed to create legal and economic preconditions for the sustainable functioning of all forms of ownership in the issues of land ownership and use" [19, p. 137-138].

Some researchers emphasize that land as an object of law and land relations must be studied considering its purpose, forms of ownership, methods of use, i.e. "taking into account the legal status of land, land plots and their parts". Land as a single state land fund or land of corresponding categories is an object of state sovereignty, the territory of the state or an administrativeterritorial unit to which protection and regulatory norms are applied. The concept of land can be considered as an integrated object consisting of a large number of natural components: it is "part of the earth's crust and natural landscape, surface area and topography of the globe, territorial space and territory of the state, certain area and place of residence, soil layer, means of economic use, spatial basis, natural object and part of the environment" [3, p. 22-23].

According to Articles 13, 14, 41, 142 of the Constitution of Ukraine, the term "land" is used in several meaning, namely as the object of property rights of the Ukrainian people; the object of property rights of citizens, legal entities and the state; object of the law of the territorial community; the object of special protection by the state (national wealth).
Thus, land as an object of property of the Ukrainian people is located above the subsoil, territorially limited by the borders of Ukraine, integral, immovable surface soil and occupied by natural resources layer, which is the basis of the landscape and spatial basis for a balanced distribution of settlements, human activities, and nature reserve fund taking into account economic, social, ecological and other interests of society, which belongs to the Ukrainian people on the right of ownership and is subject to special protection by the state as the primary national wealth [16, p. 15].

Scientific and theoretical analysis of the norms enshrined in the Constitution of Ukraine shows that Article 13 establishes a legal model for the exercise of ownership of land and other natural resources of the Ukrainian people, the essence of which is based on the fact that these environmental objects within the territory of Ukraine, its continental shelf and the exclusive marine (economic) zone are objects of property rights of the Ukrainian people, which is an independent subject of ownership of these objects.

The Ukrainian people may directly exercise the powers of possession, use and disposal of land and other natural resources in the forms and limits specified by the state's Basic Law. In addition, the right of ownership may be exercised on their behalf by authorized state and local governments. The originality of the legal ideas enshrined in the Constitution of Ukraine on the exercise of ownership of natural resources of the Ukrainian people is based on the modern scientific perception of environmental objects in a systemic relationship of land - man - society - nature. Moreover, the Constitution of Ukraine legally objectifies the natural right to natural resources into the legal right of ownership of the Ukrainian people. It obliges the state to protect land and other natural resources as a national treasure [7].

The land and other natural resources subjects are the Ukrainian people and public authorities, and local governments. According to the preamble of the Constitution of Ukraine, the Ukrainian people are citizens of Ukraine of all nationalities and an independent subject of ownership that own, use and dispose of land and other natural resources within the territory of Ukraine, as well as natural resources of the continental shelf and the exclusive (marine) economic zone. 
The right of Ukrainian people's land ownership is:

a) absolute, unchangeable, permanent, determining for the establishment of the legal regime of other natural resources;

b) may not be limited by any laws of Ukraine;

c) provides for the receipt of absolute and relative value added (capital), which must be assigned through social forms of distribution in compliance with the proportions of the progressive development of society;

d) exercises the exclusive right to dispose of land by changing the territory of Ukraine, alienation, exchange of its shares with other subjects of international law, does not allow disposition of military bases of foreign states on the territory of Ukraine.

On behalf of the Ukrainian people, landowners' rights to land are exercised exclusively by the state and local self-government bodies within the powers defined by the Constitution of Ukraine while maintaining the permanence and immutability of the right of ownership of the land of the Ukrainian people within the territory of Ukraine and impossibility of the exercise of this right by other entities without constitutional changes that are not provided by the Basic Law subjects [7].

Nosik V. [15, p. 276] expresses the opinion that land as an object of property rights of the Ukrainian people is connected with the fact that the sovereignty of Ukraine extends to its entire territory, and people are the bearer of sovereignty and the only source of power. Consolidating the supremacy of the people throughout the territory, which is occupied by Ukraine and limited to borders with other countries, the Constitution of Ukraine reflects the attitude (right) of the Ukrainian people to land as a state, as an object of nature, and not as specific areas demarcated on the land of the state for a particular use. The Constitution defines spatial boundaries of the sovereignty of the Ukrainian people, enshrines the right of the supremacy of the people to land as an expression of political domination over a specific part of the globe.

Shevchenko Y. [24, p. 275-276] considers that "the existence of Ukraine as a sovereign, unitary, independent, democratic, social and legal state can be considered as one of the main guarantees that give the Ukrainian people the opportunity to freely and independently own, use and dispose of the land within the state territory, ensure the use of land and other natural resources in the national interests of Ukraine, use all legal and institutional methods and means of protection of land ownership provided by the Constitution of Ukraine and international legal acts from any encroachments and territorial claims by other states".

According to Percheklii I. [20, p.77], the Constitution of Ukraine "considers natural resources in general as the national wealth of Ukraine, i.e. such a set of resources that performs various functions in the economy, public life, which determines the support and preservation of the people in this area". At the same time, land resources are separated from the corresponding complex of national wealth. The land is given a primary role in its structure due to the diversity of functions performed by land resources. After all, the land is considered in the Constitution of Ukraine from the standpoint of its social purpose, as a primary natural resource and place of life, as well as the basis of society, as an object necessary to meet not only material but other human needs as well, and without which man's existence is impossible. At the same time, the attribution of land to the main national wealth automatically removes the obligation to apply any legal analogies created by the legislator or jurisprudence, allows us to move away from the notion of balancing public and private interests, which have developed on a fundamentally different industry material from the standpoint of differences between the legal regime of land and the regime of other objects of public importance.

Having analyzed relevant constitutional norms, we can conclude that the right of ownership of land as an object of property of the Ukrainian people is guaranteed by Parts 2 and 4 of Article 13 the right of every citizen to use natural objects (including land), equality of all objects of legal property rights); Article 21 (all human beings are equal and free in their dignity and rights; human rights and freedoms are inalienable and inviolable); Article 22 (constitutional rights and freedoms of man and citizen are guaranteed and cannot be revoked; when adopting new laws or amending them, the content and scope of existing rights and freedoms may not be narrowed; Article 24 (citizens have equal constitutional rights and freedoms and are equal before the law); Article 41 of the Constitution of Ukraine (everyone has the right to own, use and dispose of their property; use of property may not harm the 
rights, freedoms and dignity of citizens, the interests of society, worsen the environmental situation and natural qualities of land).

The constitutional provision that land is the central national wealth, which is under the special protection of the state primarily and directly relates to land provided for agricultural production, agricultural, research and educational activities, location of relevant production infrastructure or intended for these purposes, i.e. agricultural land. These lands are used as the primary means of production in agriculture, and they are the basis of the economic development of the state and people's welfare in Ukraine. All this proves the unique natural properties of land, its extraordinary value for human existence, and society's functioning.

Drozd Y. distinguishes the following characteristic features of the land as the leading national wealth [2, p. 24-25]:

a) priority in legal regulation among other objects of national wealth;

b) subordination of the regimes of other objects of national wealth to the main object "land";

c) conditionality of independent legal regulation of relations in which the land acts as an independent object or determines the features of other objects that are biologically related to it or located on it;

d) ownership of land as the primary national wealth for the right of ownership of the Ukrainian people;

e) existence of a special regime of land protection by the state legal means at the national and transnational levels.

Analysis of constitutional provisions gives grounds to argue that the right of ownership of land is declared in two forms:

- land and its natural resources as natural objects of ownership of the Ukrainian people, the leading national wealth, which is under the special protection of the state and is the primary natural resource of the Ukrainian people (all citizens);

- land plots (borders) as objects of civil rights, which are owned by citizens, legal entities or the state and are the subject of civil transactions (purchase, sale, lease, pledge, etc.).

As noted by Bondar 0. [1, p. 17], "according to the understanding of the dual structure of the right of public (state and communal) ownership of land "that is based on the constitutional principle of ownership of the land of the Ukrainian within the territory of Ukraine, it is appropriate to consider the power of management in the field of land use and protection as a necessary element of property rights of the state, territorial communities in land relations. This authority is inherent only in these subjects of land ownership, and it is largely regulated by land legislation" and.... "any attempts to exhaustively differentiate objects of public ownership of land from others objects of land ownership will lead to a revision of the Constitution of Ukraine.

Today, the conditional delimitation of these objects can be traced in the plane of implementation of state and local government functions in the field of land relations". The scientist believes that the only criterion for the conditional delimitation of land ownership of the Ukrainian people and the state territorial communities is state bodies and local governments [1, p. 11-12].

This approach should be considered in the delimitation of land ownership of the Ukrainian people and all other subjects of property rights. In particular, the right of the people to own land is absolute in determining the forms of use of such property or disposal of land until the change of the state border. Instead, a particular landowner (in the process of the initial distribution of land by public authorities and local governments authorized to represent the Ukrainian people) receives a limited right without absolute freedom to use and dispose of land, as the limits of such freedom are predetermined by land legislation, in particular a moratorium on land expropriation. In addition, it is indisputable that private ownership of land can be alienated in the public interest against the will of such owner, while ownership of land within the state border can be changed only by the owner's decision, i.e. the Ukrainian people.

Attempts to revise constitutional norms from the right of land ownership of the Ukrainian people to the exclusivity of state ownership of all lands within the state border (with the exception established) is an obvious substitution of concepts based on the doctrine of the Soviet legal thought concerning the identification of the state and national land ownership. According to Kostiashkin I. [9, p. 209], the people's property rights are primary, and other subjects' rights are derivative. Thus, for example, suppose the people do not allow private ownership of land because of the na- 
tional, cultural or other features or traditions. In that case, the latter may be transferred to appropriate forms of land use, but this is determined by the primary owner, i. e., the people. Instead, democratic state formations must guarantee the people's interests, and the state is obliged to the people.

Ozimok I. distinguishes the following forms of an object of land relations:

1) land as the property of the Ukrainian people;

2) land as state property;

3) land as communal property;

4) land as private property.

Land as an object of the constitutional right of ownership of the land of the Ukrainian people is "a part of the globe with its inherent geographical location, an element of nature that covers an integrally fixed surface layer of the earth's crust, which serves as the spatial basis and territorial basis of Ukraine". Therefore, the object of the constitutional right of state ownership of land is all lands (land plots) of Ukraine referred to as state property by law that is not communal and private ownership.

The object of the constitutional right of communal ownership of land is all lands (land plots) within the settlements, except for lands of private and state ownership and land plots outside them. The objects of communal property are located. The object of the constitutional right of private ownership of land is land plots with established boundaries and a specific location, the ownership of which is acquired and sold by individuals and legal entities in the manner prescribed by law [17, p. 153-154].
Based on a systematic interpretation of constitutional norms, Karakhanian K. and Olkina O. argue that land is the object of constitutional regulation because it is the basis of the territory of the state, and therefore its integral element, on the one hand, and on the other hand, it is the basis for meeting basic needs of citizens of Ukraine. Because land as a natural resource and the primary means of production creates the basis for human life, it is defined by the Basic Law as the national wealth that requires special legal protection by the state and is fixed as a whole within the territory of Ukraine owned by people. In addition, the Constitution of Ukraine establishes a regime of dual ownership of land in Ukraine: both the Ukrainian people and other legal entities (state, territorial communities, individuals and legal entities), which creates some uncertainty in the implementation of land ownership by the latter [5, p. 39-40].

\section{CONCLUSIONS}

In the Constitution of Ukraine, the term "land" is used in several senses, namely as the object of property rights of the Ukrainian people; the object of property rights of citizens, legal entities and the state; the object of the law of the territorial community; the object of special protection by the state (national wealth). Specific features of the land as the object of legal relations determine the content of land relations and the scope of rights and obligations of the subjects of these legal relations. Thus, basic principles of land relations are declared in the Constitution of Ukraine and have analyzed. It can be argued that a land is a unique object of legal relations, a part of the globe and an element of nature that covers the surface layer of the earth's crust.

\section{REFERENCES}

1. Bondar, 0. (2005). Zemlia yak ob'iekt prava vlasnosti za zemelnym zakonodavstvom Ukrainy [The land as an object of the right of ownership according to the land legislation of Ukraine] (Doctoral thesis), Instytut derzhavy i prava im. V.M. Koretskoho. Kyiv (in Ukrainian) [Бондар, О. (2005). Земля як об'єкт права власності за земельним законодавством України (Автореферат кандидатської дисертації), Інститут держави і права ім. В.М. Корецького. Київ].

2. Drozd, O. (2009). Zemlia yak ob'iekt zemelnykh vidnosyn [Land as an object of land relations]. Advokat, 1, 23-26 (in Ukrainian) [Дрозд, О. (2009). Земля як об’єкт земельних відносин. Адвокат, 1, 23-26].

3. Karakash, I., \& Kharytonova, T. (Eds). (2017). Zemelne pravo Ukrainy [Land law of Ukraine] (2nd ed.). Odesa: Yurydychna literatura (in Ukrainian) 
[Каракаш, I., \& Харитонова, Т. (Ред.). (2017). Земельне право України (2-ге вид.). Одеса: Юридична література].

4. Zemelnyi kodeks Ukrainy [Land Code of Ukraine] (Ukraine), 25.10.2001, No 2768-III. Retrieved April 1, 2021, from https://zakon.rada.gov.ua/laws/show/2768-14\#Text (in Ukrainian)

[Земельний кодекс України (Україна), 25.10.2001, № 2768-III. Актуально на 01.04.2021. URL: https://zakon.rada.gov.ua/laws/show/2768-14\#Text].

5. Karakhanian, K., \& Olkina, O. (2019). Constitutional foundations for the acquisition and implementation of ownership on a certain type of lands in Ukraine: legal conflicts and ways of overcome. Problems of Legality, 147, 37-45. doi: 10.21564/2414-990x.147.182495

6. Konstytutsiia Ukrainy [The Constitution of Ukraine] (Ukraine), 28 June 1996. Retrieved April 1, 2021, from https://zakon.rada.gov.ua/laws/show/254\%D0\%BA/96-\%D0\%B2\%D1\%80 (in Ukrainian)

[Конституція України (Україна), 28 червня 1996 р. Актуально на 01.04.2021.

URL: https://zakon.rada.gov.ua/laws/show/254\%D0\%BA/96-\%D0\%B2\%D1\%80].

7. Konstytutsiia Ukrainy. (2021). Stattia 13 Konstytutsii Ukrainy [Article 13 of the Constitution of Ukraine]. Retrieved May 1, 2021, from https://konstitutsiya.com.ua/st-13 (in Ukrainian) [Конституція України. (2021). Стаття 13 Конституції України. Актуально на 01.05.2021. URL: https://konstitutsiya.com.ua/st-13].

8. Kostiashkin, I. (2017). Okremi aspekty realizatsii prava vlasnosti na zemliu ukrainskoho narodu [Separate Aspects of Realization of Land Ownership of the Ukrainian People]. Universytetski naukovi zapysky, 63, 204-214 (in Ukrainian)

[Костяшкін, I. (2017). Окремі аспекти реалізації права власності на землю українського народу. Університетські наукові записки, 63, 204-214].

9. Kostiashkin, I. (2012). Sotsialna funktsiia prava vlasnosti yak umova staloho vykorystannia zemel [Social function of land ownership in Ukraine: concepts and essential features]. Pravo Ukrainy, 6, 181-188 (in Ukrainian)

[Костяшкін, I. (2012). Соціальна функція права власності як умова сталого використання земель. Право України, 6, 181-188].

10. Kulynych, P. (2001). Konstytutsiini aspekty prava vlasnosti na zemli silskohospodarskoho pryznachennia [Constitutional aspects of ownership of agricultural land]. In V. Semchyk (Ed.), Problemy prava vlasnosti ta hospodariuvannia u silskomu hospo-darstvi (p. 66-69). Kyiv: Instytut derzhavy i prava im. V. M. Koretskoho (in Ukrainian)

[Кулинич, П. (2001). Конституційні аспекти права власності на землі сільськогосподарського призначення. В В. Семчик (Ред.), Проблеми права власності та господарювання у сільському господарстві (с. 66-69). Київ: Інститут держави і права ім. В.М. Корецького].

11. Kulynych, P. (2011). Okhorona zemli yak osnovnoho natsionalnoho bahatstva: konstytutsiinyi aspekt [protection of land as the main national wealth: the constitutional aspect]. Chasopys Kyivskoho universytetu prava, 1, 236-240 (in Ukrainian)

[Кулинич, П. (2011). Охорона землі як основного національного багатства: конституційний аспект. Часопис Київського університету права, 1, 236-240].

12. Myronenko, I. (2012). Zmist ta mezhi zdiisnennia prava pryvatnoi vlasnosti na zemliu v Ukraini [Content and limits of exercising the right of private ownership of land in Ukraine]. IvanoFrankivsk: Vydavets Suprun V. P. (in Ukrainian)

[Мироненко, I. (2012). Зміст та межі здійснення права приватної власності на землю в Україні. Івано-Франківськ: Видавець Супрун В. П.].

13. Miroshnychenko, A. (2011). Zemelne pravo Ukrainy [Land law of Ukraine] (2nd ed.). Kyiv: Pravova yednist (in Ukrainian)

[Мірошниченко, А. (2011). Земельне право України (2-ге вид.). Київ: Правова єдність]. 
14. Myroshnychenko, A. (2016). Kolizii v pravovomu rehuliuvanni zemelnykh vidnosyn v Ukraini [Conflicts in the legal regulation of land relations in Ukraine]. Kyiv: Pravova yednist (in Ukrainian)

[Мірошниченко, А. (2016). Колізії в правовому регулюванні земельних відносин в Україні. Київ: Правова єдність].

15. Nosik, V. (2006). Pravo vlasnosti na zemliu ukrainskoho narodu [Land ownership of the Ukrainian people]. Kyiv: Yurinkom Inter (in Ukrainian)

[Носік, В. (2006). Право власності на землю украӥнського народу. Київ: Юрінком Інтер].

16. Nosik, V. (2007). Problemy zdiisnennia prava vlasnosti na zemliu ukrainskoho narodu [Issues of exercising the right of land ownership of Ukrainian people] (Doctoral thesis), Kyivskyi natsionalnyi universytet imeni Tarasa Shevchenka. Kyiv (in Ukrainian) [Носік, В. (2007). Проблеми здійснення права власності на землю українського народу (Автореферат докторської дисертації), Київський національний університет імені Тараса Шевченка. Київ].

17. Ozimok, I. (2020). Konstytutsiine pravo vlasnosti na zemliu v Ukraini ta zarubizhnykh krainakh: porivnialno-pravove doslidzhennia [Constitutional right to land ownership in Ukraine and foreign countries: comparative law research] (Doctoral dissertation), Natsionalna akademiia vnutrishnikh sprav. Kyiv (in Ukrainian)

[Озімок, I. (2020). Конституційне право власності на землю в Україні та зарубіжних країнах: порівняльно-правове дослідження (Кандидатська дисертація), Національна академія внутрішніх справ. Київ].

18. Ozimok, I. (2019). Konstytutsiino-pravove rehuliuvannia prava vlasnosti na zemliu v Ukraini [Constitutional and Legal Regulations of Land Ownership Rights in Ukraine]. Istoryko-pravovyi chasopys, 2(14), 129-134 (in Ukrainian)

[Озімок, I. (2019). Конституційно-правове регулювання права власності на землю в Україні. Історико-правовий часопис, 2(14), 129-134].

19. Pakhomov, V. (2016). Administratyvno-pravove zabezpechennia kontrolno-nahliadovoi diialnosti u sferi zemelnykh vidnosyn [Administrative and legal support of control and supervision activities in the field of land relations]. Sumy: Sumskyi derzhavnyi universytet (in Ukrainian) [Пахомов, В. (2016). Адміністративно-правове забезпечення контрольно-наглядової діяльності у сфері земельних відносин. Суми: Сумський державний університет].

20. Percheklii, I. (2015). Pravo vlasnosti ukrainskoho narodu na pryrodni resursy: ekoloho-pravovi zasady [The right of ownership of the Ukrainian people to natural resources: environmental and legal principles] (Doctoral dissertation), Instytut derzhavy i prava im. V. M. Koretskoho. Kyiv (in Ukrainian)

[Перчеклій, I. (2015). Право власності українського народу на природні ресурси: екологоправові засади (Кандидатська дисертація), Інститут держави і права ім. В. М. Корецького. Київ].

21. Pro deiaki pytannia praktyky rozghliadu sprav u sporakh, shcho vynykaiut iz zemelnykh vidnosyn [On some issues of the practice of consideration of cases in disputes arising from land relations] (Ukraine), 17.05.2011, No 6. Retrieved May 1, 2021, from https://zakon.rada.gov.ua/laws/show/v0006600-11\#Text (in Ukrainian)

[Про деякі питання практики розгляду справ у спорах, що виникають із земельних відносин (Україна), 17.05.2011, № 6. Актуально на 01.05.2021. URL:

https://zakon.rada.gov.ua/laws/show/v0006600-11\#Text].

22. Sydor, V. (2011). Zahalna kharakterystyka konstytutsiinykh osnov zemelnoho prava Ukrainy [General characteristics of the constitutional foundations of land law of Ukraine]. Yuryst Ukrainy, 1(14), 45-50 (in Ukrainian)

[Сидор, В. (2011). Загальна характеристика конституційних основ земельного права України. Юрист України, 1(14), 45-50]. 
23. Sydor, V. (2011). Klasyfikatsiia norm, shcho stanovliat konstytutsiini osnovy zemelnoho prava Classification of norms that constitute the constitutional basis of land law]. Chasopys Kyivskoho universytetu prava, 1, 249-253 (in Ukrainian)

[Сидор, В. (2011). Класифікація норм, що становлять конституційні основи земельного права. Часопис Київського університету права, 1, 249-253].

24. Shevchenko, Ya. (2006). Ukrainskyi narod yak sub'iekt prava vlasnosti na zemliu [Ukrainian people as a subject of land ownership]. Visnyk Akademii pravovykh nauk Ukrainy, 3(46), 274-277 (in Ukrainian)

[Шевченко, Я. (2006). Український народ як суб’єкт права власності на землю. Вісник Академії правових наук Украӥни, 3(46), 274-277]. 